\title{
Late Holocene environmental change and human impact inferred from three soil monoliths and the Laguna Zurita multi-proxi record in the southeastern Ecuadorian Andes
}

\author{
Holger Niemann $\cdot$ Hermann Behling
}

Received: 5 May 2009/ Accepted: 7 July 2009/Published online: 4 September 2009

(c) The Author(s) 2009. This article is published with open access at Springerlink.com

\begin{abstract}
Late Holocene vegetation, climate and fire dynamics of mountain forest and paramo ecosystems, as well as human impact, are presented from the upper Rio San Francisco valley, southeastern Ecuadorian Andes. Palaeoenvironmental changes, inferred from three soil monoliths, spanning an altitudinal gradient between 1,990 and 3,200 $\mathrm{m}$ and the high resolution multi-proxy sediment record from Laguna Zurita $(2,590 \mathrm{~m})$, were investigated by pollen, spore and charcoal analyses, in combination with XRF- and magnetic susceptibility-scanning. Three of the four pollen records show a marked change in the floristic composition between ca. 900 and 350 cal B.P. (interpolated age). Past fires have strongly influenced the floristic composition of the mountain rainforest ecosystem. Frequent fires, together with the relatively high occurrence of grasses and some Zea mays plantations document past human activities in the upper Rio San Francisco valley. A large number of areas of probably ancient $Z$. mays cultivation in the upper Rio San Francisco valley has been identified, using GIS-based calculation. High occurrences of Cyperaceae and Isoetes indicate the development of marshy lake shores in response to a lower lake level at Laguna Zurita before ca. $700 \mathrm{cal}$ B.P. The decrease of Isoetes and Cyperaceae after ca. 1200 cal B.P. reflects a lake level rise, due to increasing moisture and/or human activities.
\end{abstract}

Communicated by E. Grimm.

H. Niemann $(\bowtie) \cdot H$. Behling

Department of Palynology and Climate Dynamics,

Albrecht-von-Haller-Institute for Plant Sciences,

University of Göttingen, Untere Karspüle 2,

37073 Göttingen, Germany

e-mail: holnie@web.de
Keywords Human impact - Vegetation development . Climate change $\cdot$ Pollen analysis $\cdot$ XRF-scanning . GIS

\section{Introduction}

The Ecuadorian Andes harbour the most species-rich ecosystems on earth (Barthlott et al. 2005). Despite their high biodiversity, huge areas have suffered from human disturbance, in particular during the last decades. Natural vegetation regeneration and sustainable management is urgently needed, as well as conservation of less degraded areas.

To study the highly diverse mountain ecosystems in south-eastern Ecuador, extended research has been carried out within the framework of the "Deutsche Forschungsgemeinschaft" (DFG) research group "Tropical Mountain Ecosystems" focusing on Podocarpus National Park (Beck et al. 2008a). Currently (2007-2010) more than 25 different research groups are working in the Estacion Cientifica San Francisco (ECSF) research area. Palaeoecological analyses of more than ten different lake, peat and soil cores in the Podocarpus National Park region started in 2005 (Matthias 2008; Niemann 2008; Niemann and Behling 2008; Niemann and Behling 2009a, b; Niemann et al. 2009). This palaeoecological information is needed to understand the development and dynamics of modern ecosystems for proper management and conservation.

Few palaeoenvironmental records are available from southern Ecuador and neighbouring regions. Examples of these are from Lake Ayauch in the southeastern part of Ecuadorian Amazonia (Bush and Colinvaux 1988), from Rio Napo (Yasuni National Park) in the northwestern Amazon basin of Ecuador (Colinvaux et al. 1988a; Weng et al. 2002), from Lake Yambo at the Inter-Andean plateau 


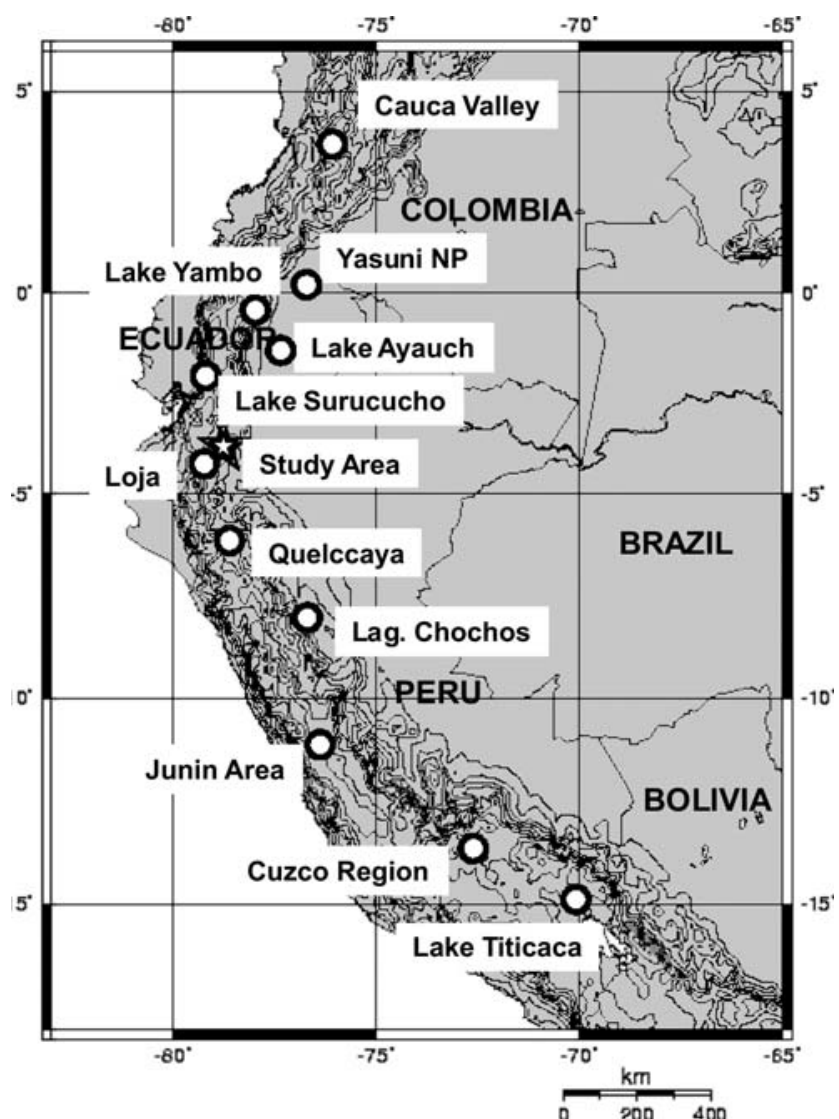

Fig. 1 Map of central northwestern tropical South America, showing the study site (star) and other locations discussed in the text (circles)

of Ecuador (Colinvaux et al. 1988b), from Lake Surucucho in the central Ecuadorian Andes (Colinvaux 1997), from the Colombian Cauca Valley (Berrio et al. 2002), from Laguna de Chochos in the eastern Peruvian Andes (Bush et al. 2005), from the Junin area in the central Peruvian Andes (Hansen et al. 1984, 1994), from Quelccaya ice-core in the central Peruvian Andes (Thompson et al. 1984, 1986, 2003), from Lake Titicaca and the surrounding BolivianPeruvian Altiplano (Binford et al. 1997) and from the Cuzco region in Peru (Chepstow-Lusty et al. 2003). Locations of greater interest for this study are shown in Fig. 1.

\section{Site description}

Location

The Andes of southern Ecuador and northern Peru include the so-called Andean depression (Depression de GironCuenca in Ecuador and Huancabamba in Peru), an approximately $\mathrm{N}-\mathrm{S}$ oriented topographic depression. The main peaks of the mountains in this region only reach up to elevations of about 4,000 m. Active volcanoes are absent (Richter and Moreira-Munoz 2005). The main structural limits of the depression are reactivated crustal scale faults, which formed during successive Cretaceous and early Tertiary accretionary events along the Ecuadorian continental margin. The southern Cordillera Real is mainly composed of the geologic unit of the "Zamora series", consisting of Palaeozoic metamorphic rocks of widely varying metamorphic grade. Local bedrock is dominated by semipelites, quartzites and black phylites with some granitic intrusions (Litherland et al. 1994).

The study site (Fig. 2) is located on the eastern slope of the eastern Cordillera (Cordillera Real) between the cities of Loja $(2,200 \mathrm{~m})$ and Zamora $(1,000 \mathrm{~m})$, north of the Podocarpus National Park in the E-W exposed upper Rio San Francisco valley. The ECSF research area $\left(3^{\circ} 58^{\prime} 30^{\prime \prime} \mathrm{S}\right.$, $79^{\circ} 4^{\prime} 25^{\prime \prime} \mathrm{W}$ ), covering about $1,100 \mathrm{ha}$, is a part of the study site located west of the small village of Sabanilla on a mountain ridge system about $5 \mathrm{~km}$ long with a north-south orientation, between 1,800 and $3,200 \mathrm{~m}$ in elevation. Laguna Zurita $\left(3^{\circ} 58^{\prime} 28.8^{\prime \prime} \mathrm{S}, 7^{\circ} 07^{\prime} 03.4^{\prime \prime} \mathrm{W}, 2,590 \mathrm{~m}\right)$ is about $2,000 \mathrm{~m}^{2}$ in size and $3 \mathrm{~m}$ deep. It is located about $4 \mathrm{~km}$ west of the ECSF research area, exposed on a flat mountain ridge in a small depression about $200 \mathrm{~m}$ above the old road from Loja to Zamora.

\section{Modern vegetation}

The description of recent vegetation of the ECSF research area follows the fieldwork data of the research group "Tropical Mountain Ecosystems" (Homeier et al. 2008) (Table 1).

The lower montane forest (LMF) occurs between ca. 1,300 and 2,100 $\mathrm{m}$ with an extremely diverse, two-storied tree stratum and a canopy height up to $30 \mathrm{~m}$. Undisturbed communities of this type can be found particularly on steep slopes with $30-50^{\circ}$ inclination, as well as up to ca. 2,300 m at the bottom of wind-protected river valleys. The upper montane forest (UMF) occurs between ca. 2,100 and $2,700 \mathrm{~m}$, showing a low, monotypic formation, with only one tree stratum. The canopy heights attain up to $25 \mathrm{~m}$. Between ca. 2,700-3,100 m subparamo (elfin-forest) vegetation occurs. This forest type forms the upper timberline with a canopy height rarely up to 6-8 m. The paramo occurs in the crest region of the Cordillera Real above the upper timberline between ca. 3,100-3,700 m. This vegetation type attains heights of up to $2 \mathrm{~m}$.

\section{Climate}

The climate of Ecuador is dominated by the tropical trade wind regime, which is well established in the mid- and higher troposphere, with strong easterly winds throughout 


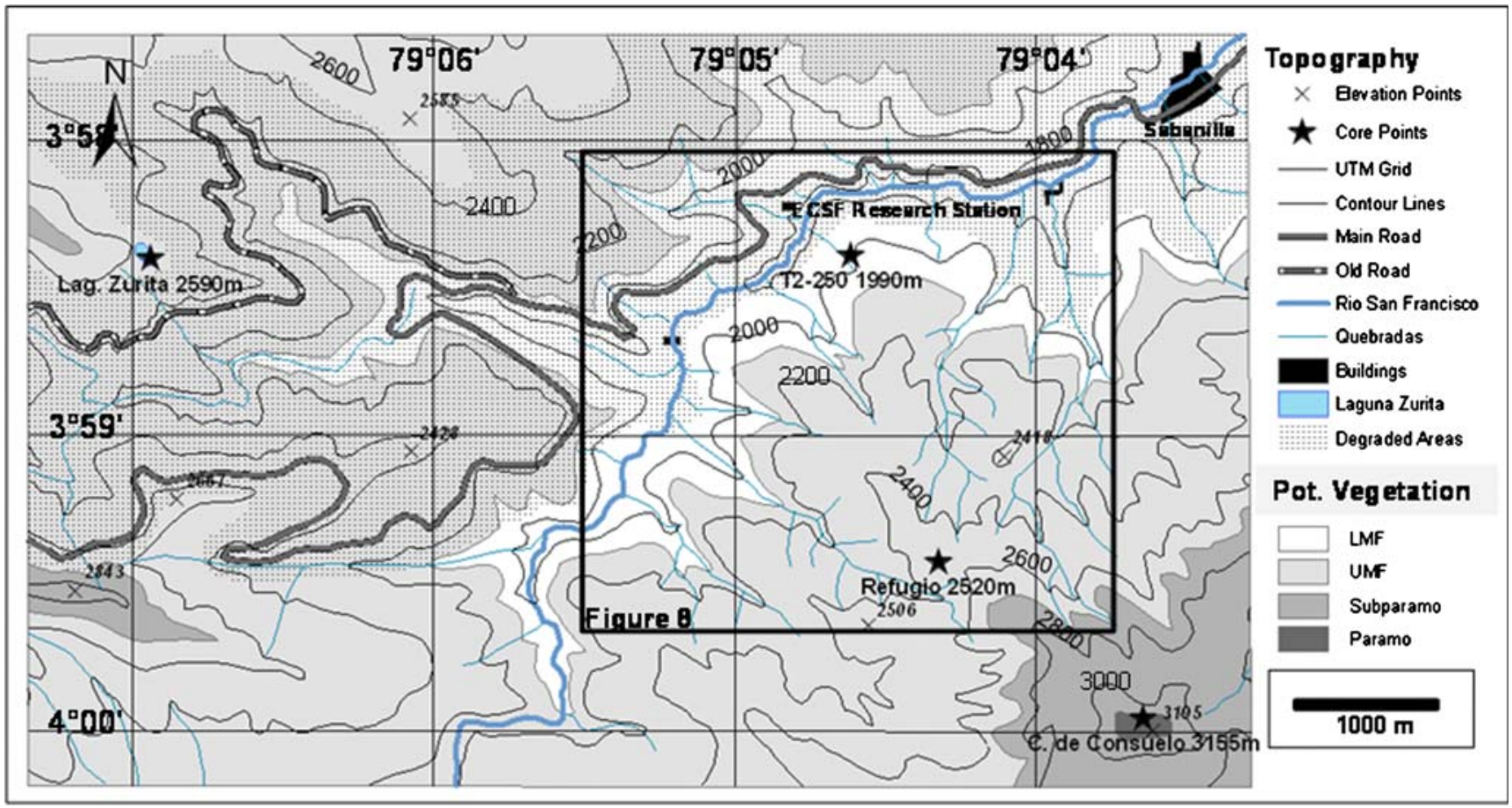

Fig. 2 GIS-based map of the upper Rio San Francisco valley, on the basis of Mapa Topográfico del Ecuador 1:50,000, Hoja Loja Sur 3781- I

the year. The surface wind field is locally and regionally modified by the complex topography of the Andes and the thermal land-sea contrast at the Pacific coast. The southeastern part of the country, encompassing the ECSF research area is mainly influenced by easterly winds. Westerly winds occasionally occur especially in austral summer. The main rainy season lasts from April to August even if rainfall is high all through the year (Beck et al. 2008b). As part of the so-called Andean depression, all summits in the southern Ecuadorian Andes are below the snowline.

The Cordillera Real forms a division that separates the moist eastern slopes of the Andes from the dry innerAndean basins (e.g., the Loja and Catamayo Basins). Between the eastern slopes of the Cordillera Real and the dry valley of Catamayo, which are only $70 \mathrm{~km}$ apart, annual rainfall values drop from over 4,000 to $300 \mathrm{~mm} \mathrm{year}^{-1}$ (Bendix et al. 2004).

The precipitation patterns in the ECSF research area show a strong altitudinal gradient, an increase in precipitation with elevation from the valley bottom $(1,800 \mathrm{~m})$ to crest region $(3,200 \mathrm{~m})$. Measured precipitation data, including cloud/fog water deposition for the years 1998-2005 are available for the ECSF research station $(1,960 \mathrm{~m}) \quad 2,297 \mathrm{~mm} \mathrm{year}^{-1}$, Plataforma $(2,270 \mathrm{~m})$ 2,403 mm year ${ }^{-1}$, TS1 $(2,660 \mathrm{~m}) 5,306 \mathrm{~mm} \mathrm{year}^{-1}$ and Cerro de Consuelo (3,180 m) 6,701 $\mathrm{mm}_{\text {year }}{ }^{-1}$ (Bendix et al. 2008). The average precipitation rate near the El
Tiro-Pass $(2,880 \mathrm{~m}), 10 \mathrm{~km}$ west of the ECSF research area is about 3,500 $\mathrm{mm} \mathrm{year}^{-1}$ (Emck 2007).

\section{Materials and methods}

The ca. $50 \mathrm{~cm}$ long soil monoliths were collected at three different altitudes in the ECSF research area by excavation. The soil monoliths were taken on a small plateau at $1,990 \mathrm{~m}(\mathrm{~T} 2 / 250)$, on a flat mountain ridge at $2,520 \mathrm{~m}$ (Refugio) and in a small depression next to the summit at 3,155 m (Cerro de Consuelo). The monoliths were stored in split PVC tubes, wrapped with plastic film and kept under dark and cold $\left(+4^{\circ} \mathrm{C}\right)$ conditions before processing.

The $69 \mathrm{~cm}$ long sediment core from Laguna Zurita was raised with a Livingstone piston corer at the centre of the lake (3 $\mathrm{m}$ water depth) from two inflatable rubber rafts. The core was retained in the tube and stored under dark and cold $\left(+4^{\circ} \mathrm{C}\right)$ conditions before processing.

In total, nine subsamples (soil organic matter, bulk and charcoal fragments) were taken for Accelerator Mass Spectrometer (AMS) radiocarbon dating. Radiocarbon ages were calibrated with Calib 5.0.2 (Stuiver and Reimer 1993) using the southern hemisphere calibration curve (McCormac et al. 2004).

From the three soil monoliths a total of 73 subsamples $\left(0.25 \mathrm{~cm}^{3}\right)$ were taken at $2 \mathrm{~cm}$ intervals. From the Laguna Zurita sediment core 24 subsamples $\left(0.25 \mathrm{~cm}^{3}\right)$ were taken 
Table 1 Characteristic species of the different vegetation zones

\begin{tabular}{|c|c|c|c|}
\hline Lower Montane Forest & Upper Montane Forest & Subparamo & Paramo \\
\hline Alzatea verticillata & Ilex rimbachii & Ilex spp. & Gynoxis spp. \\
\hline (Alzateaceae) & (Aquifoliaceae) & (Aquifoliaceae) & (Asteraceae) \\
\hline Chamaedorea pinnatifrons & Hedyosmum spp. & Puya eryngioides & Puya eryngioides \\
\hline Dictyocaryum lamarckianum & (Chloranthaceae) & (Bromeliaceae) & Puya nitida \\
\hline Wettinia maynensis & Clethra revoluta & Hedyosmum cumbalense & (Bromeliaceae) \\
\hline (Arecaceae) & Purdiaea nutans & Hedyosmum scabrum & Hypericum decandrum \\
\hline Piptocoma discolor & (Clethraceae) & (Chloranthaceae) & (Clusiaceae) \\
\hline Mikania spp. & Clusia ducu & Clethra ovalifolia & Rhynchospora vulcani \\
\hline (Asteraceae) & Tovomita weddeliana & (Clethraceae) & (Cyperaceae) \\
\hline Tabebuia chrysantha & (Clusiaceae) & Clusia elliptica & Befaria resinosa \\
\hline (Bignoniaceae) & Weinmannia pinnata & (Clusiaceae) & Disterigma pentandrum \\
\hline Vismia tomentosa & Weinmannia spp. & Weinmannia cochensis & Gaultheria erecta \\
\hline (Clusiaceae) & (Cunoniaceae) & Weinmannia loxensis & Gaultheria reticulata \\
\hline Cyathea caracasana & Cyathea bipinnatifida & Weinmannia rollottii & Vaccinium floribundum \\
\hline (Cyatheaceae) & (Cyatheaceae) & (Cunoniaceae) & (Ericaceae) \\
\hline Inga acreana & Befaria aestuans & Gaultheria reticulata & Escallonia myrtilloides \\
\hline Inga spp. & (Ericaceae) & (Ericaceae) & (Grossulariaceae) \\
\hline (Fabaceae) & Alchornea grandiflora & Escallonia myrtilloides & Brachyotum andreanum \\
\hline Nectandra lineatifolia & (Euphorbiaceae) & (Grossulariaceae) & (Melastomataceae) \\
\hline Nectandra membranacea & Macrocarpaea revoluta & Orthrosanthus chimborazensis & Neurolepis asymmetrica \\
\hline Ocotea aciphylla & (Gentianaceae) & (Iridaceae) & Neurolepis elata \\
\hline (Lauraceae) & Eschweilera sessilis & Persea ferruginea & Neurolepis laegaardii \\
\hline Miconia imitans & (Lecythidaceae) & Ocotea infravoveolata & Chusquea neurophylla \\
\hline Miconia punctata & Licaria subsessilis & (Lauraceae) & (Poaceae) \\
\hline (Melastomataceae) & Ocotea benthamiana & Gaiadendron punctatum & Monnina arbuscula \\
\hline Cedrela montana & Persea ferruginea & (Loranthaceae) & (Polygalaceae) \\
\hline (Meliaceae) & (Lauraceae) & Graffenrieda harlingii & Valeriana microphylla \\
\hline Ficus spp. & Graffenrieda emarginata & (Melastomataceae) & Valeriana plantaginea \\
\hline Morus insignis & Graffenrieda harlingii & Myrteola phylicoides & (Valerianaceae) \\
\hline Sorocea trophoides & Tibouchina lepidota & (Mytraceae) & \\
\hline (Moraceae) & (Melastomataceae) & Chusquea falcata & \\
\hline Piper spp. & Myrica pubescens & Chusquea scandens & \\
\hline (Piperaceae) & (Myricaceae) & (Poaceae) & \\
\hline Heliocarpus americanus & Myrsine coriacea & Hesperomeles ferruginea & \\
\hline \multirow[t]{14}{*}{ (Tiliaceae) } & (Myrsinaceae) & (Rosaceae) & \\
\hline & Calyptranthes pulchella & Styrax foveolaria & \\
\hline & Myrcia spp. & (Styracaceae) & \\
\hline & (Mytraceae) & Symplocos sulcinervia & \\
\hline & Podocarpus oleifolius & (Symplocaceae) & \\
\hline & Prumnopitys montana & Gordonia fruticosa & \\
\hline & (Podocarpaceae) & (Theaceae) & \\
\hline & Dioicodendron dioicum & & \\
\hline & Palicourea spp. & & \\
\hline & (Rubiaceae) & & \\
\hline & Matayba inelegans & & \\
\hline & (Sapindaceae) & & \\
\hline & Drimys granadensis & & \\
\hline & (Winteraceae) & & \\
\hline
\end{tabular}


at $4 \mathrm{~cm}$ ( $2 \mathrm{~cm}$ at the lowermost core section) intervals. All samples were processed by standard methods (Faegri and Iversen 1989). Before treatment, exotic Lycopodium spores were added to each sample for calculation of pollen concentration (pollen $/ \mathrm{cm}^{3}$ ). About 300 pollen grains were counted for each sample. The pollen sum includes tree, shrub and herb pollen and excludes aquatic pollen taxa and fern spores. Cyperaceae pollen was also excluded in the pollen sum of the Laguna Zurita record. Pollen identification relied on the reference collection from the second author comprising about 3,000 slides of neotropical species and literature (Behling 1993; Hooghiemstra 1984), and a reference collection of about 300 species collected during the fieldwork and from the herbarium of the ECSF research station.

The ecological grouping of the identified pollen taxa into lower and upper mountain forest and (sub)-paramo follows available data in the literature (Homeier and Werner 2005; Homeier et al. 2008; Lozano et al. 2003). Pollen and spore data are presented in pollen diagrams as percentages of the pollen sum. Carbonized particles $(10-150 \mu \mathrm{m})$ were counted on pollen slides and presented as concentration (particles $/ \mathrm{cm}^{3}$ ). The software TILIA,
TILIAGRAPH and CONISS was used to plot the pollen and spore data (Grimm 1987). Cluster analysis (CONISS) of pollen taxa produced a dendrogram to identify the pollen zones (Figs. 3, 4, 5, 6).

Non-destructive magnetic susceptibility scanning was performed on the split core from Laguna Zurita with a Bartington MS2F point sensor at $1 \mathrm{~cm}$ resolution. Also non-destructively, an Avaatech XRF-scanner provided semi-quantitative analyses of $\mathrm{Al}, \mathrm{Si}, \mathrm{S}, \mathrm{K}, \mathrm{Ca}, \mathrm{Ti}, \mathrm{Mn}$ and Fe (Richter et al. 2006; Tjallingii et al. 2007) at $1 \mathrm{~cm}$ depth intervals. Values are given in total counts (cts) (Fig. 7).

An area of ca. $11.2 \mathrm{~km}^{2}$ (Figs. 2, 8) was selected for GIS-based (ESRI ArcGIS) reconstruction of ancient Zea mays cultivation, including the core sections of the soil monoliths of ECSF-Refugio and ECSF-T2/250 in the lower part of the ECSF research area. The topographic map (Mapa Militar, Loja Norte, scale 1:50,000) was georeferenced and digitalised, adopting the UTM-Grid, WGS 84, Zone17S. Terraces have been observed east of the village of Sabanilla and to the west in the Loja region, mostly on a slope inclination between $10^{\circ}$ and $35^{\circ}$ (Fig. 9). Zea mays pollen is not found at elevations over $2,520 \mathrm{~m}$ elevation at

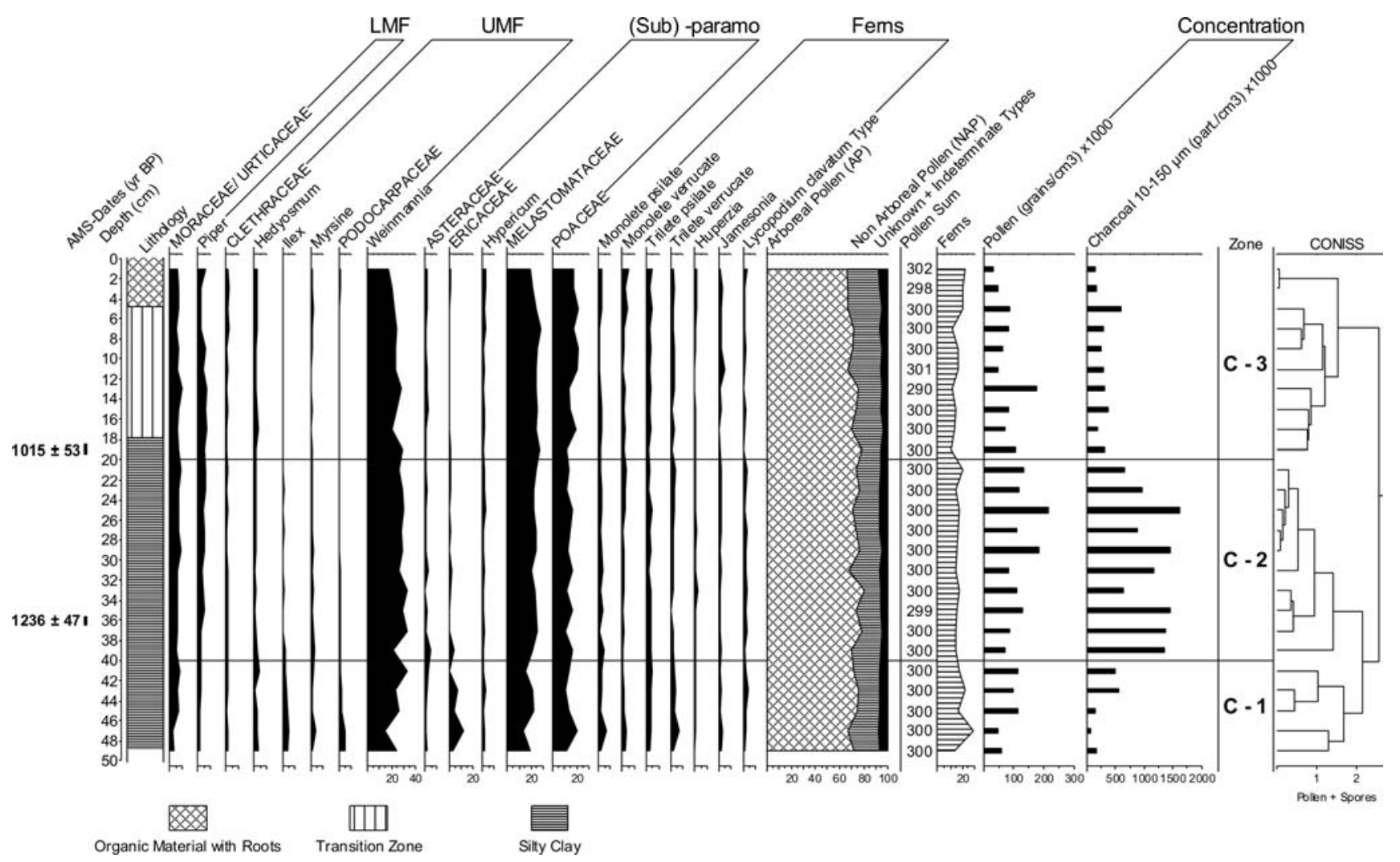

Fig. 3 Pollen percentage diagram of the soil monolith from ECSF Cerro de Consuelo (3,155 $\mathrm{m}$ elevation) showing the AMS radiocarbon dates (в.P.), the lithology, selected pollen and spore taxa grouped into lower mountain forest $(L M F)$, upper mountain forest $(U M F)$ and (sub)-paramo, sums of ecological groups, the pollen sum, pollen and charcoal concentration, the pollen zones and the CONISS dendrogram 


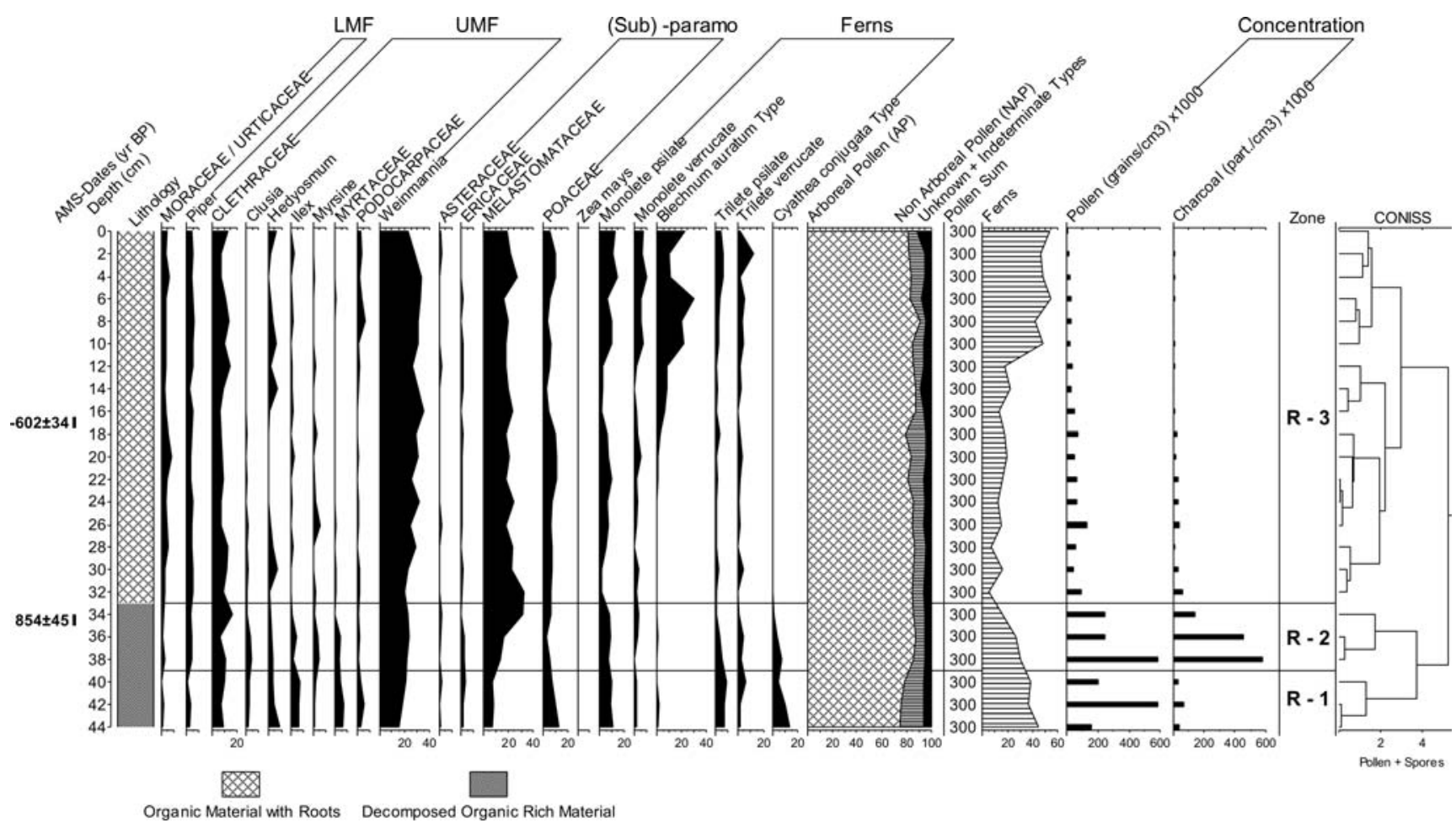

Fig. 4 Pollen percentage diagram of the soil monolith from ECSF Refugio $(2,520 \mathrm{~m}$ elevation) showing the AMS radiocarbon dates (в.P.), the lithology, selected pollen and spore taxa, grouped into

lower mountain forest $(L M F)$, upper mountain forest $(U M F)$ and (sub)-paramo, sums of ecological groups, the pollen sum, pollen and charcoal concentration, the pollen zones and the CONISS dendrogram

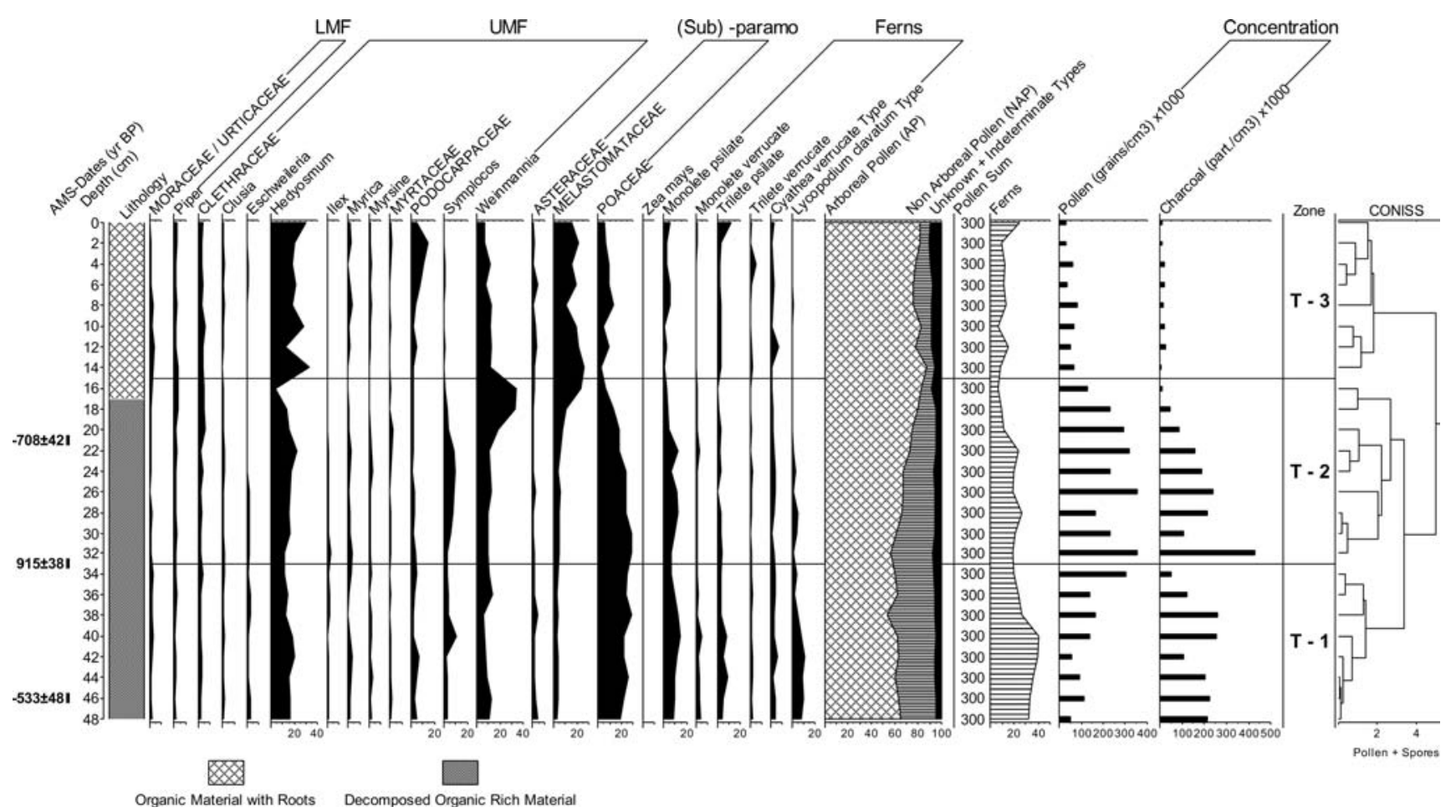

Fig. 5 Pollen percentage diagram of the soil monolith from ECSF $\mathrm{T} 2 / 250$ (1,990 $\mathrm{m}$ elevation) showing the AMS radiocarbon dates (в.P.), the lithology, selected pollen and spore taxa, grouped into lower mountain forest $(L M F)$, upper mountain forest $(U M F)$ and (sub)-paramo, sums of ecological groups, the pollen sum, pollen and charcoal concentration, the pollen zones and the CONISS dendrogram 


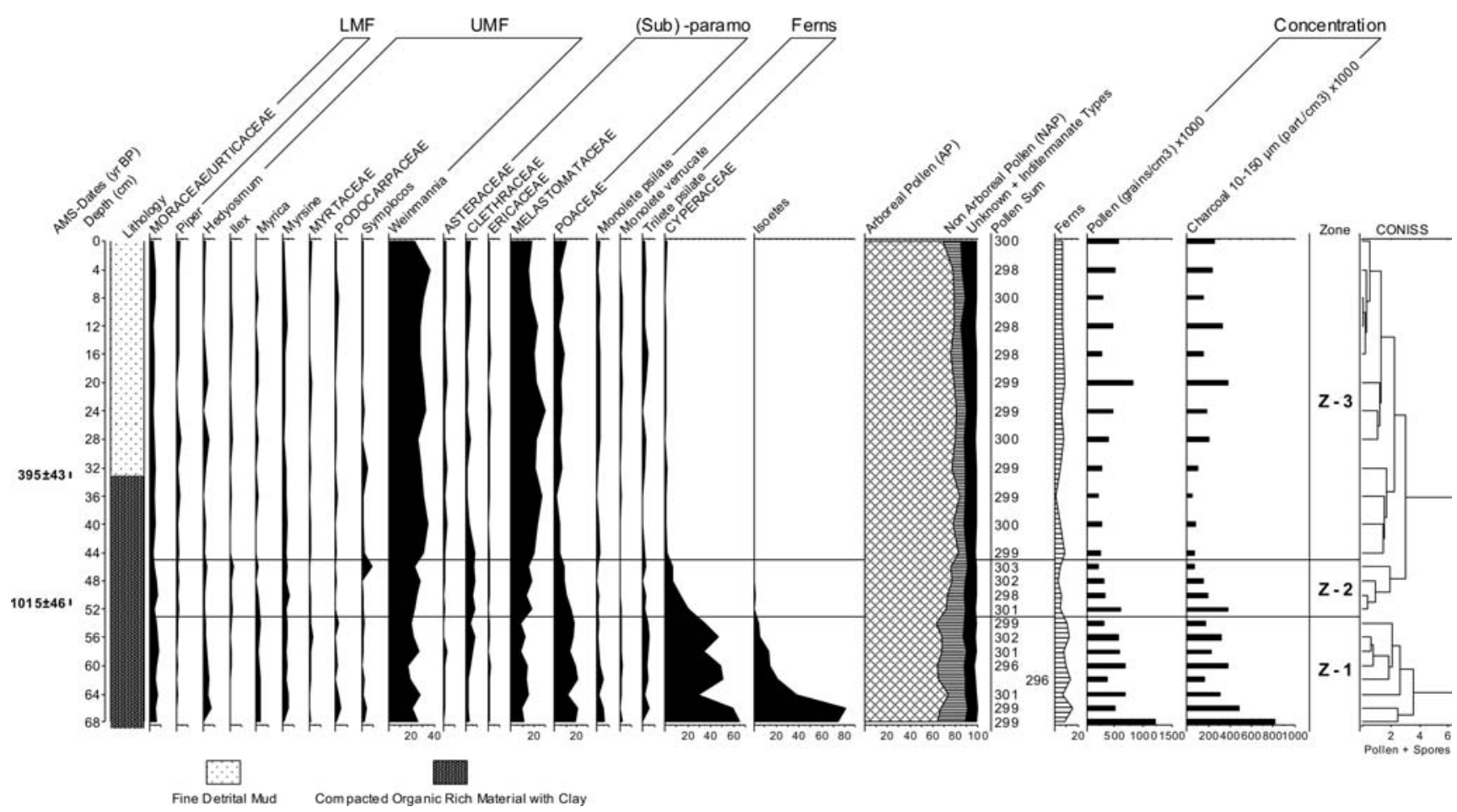

Fig. 6 Pollen percentage diagram of the Laguna Zurita $(2,590 \mathrm{~m}$ elevation) sediment core showing the AMS radiocarbon dates, sample ages (cal в.P.), the lithology, selected pollen and spore taxa, grouped into lower mountain forest (LMF), upper mountain forest (UMF) and (sub)-paramo, sums of ecological groups, the pollen sum, the deposition time, pollen and charcoal concentration, the pollen zones and the CONISS dendrogram

Fig. 7 Diagram of physical properties showing the AMS radiocarbon dates, sample ages (cal в.P.), the sedimentation rate, XRF-data and magnetic susceptibility and the pollen zones of Laguna Zurita sediment core

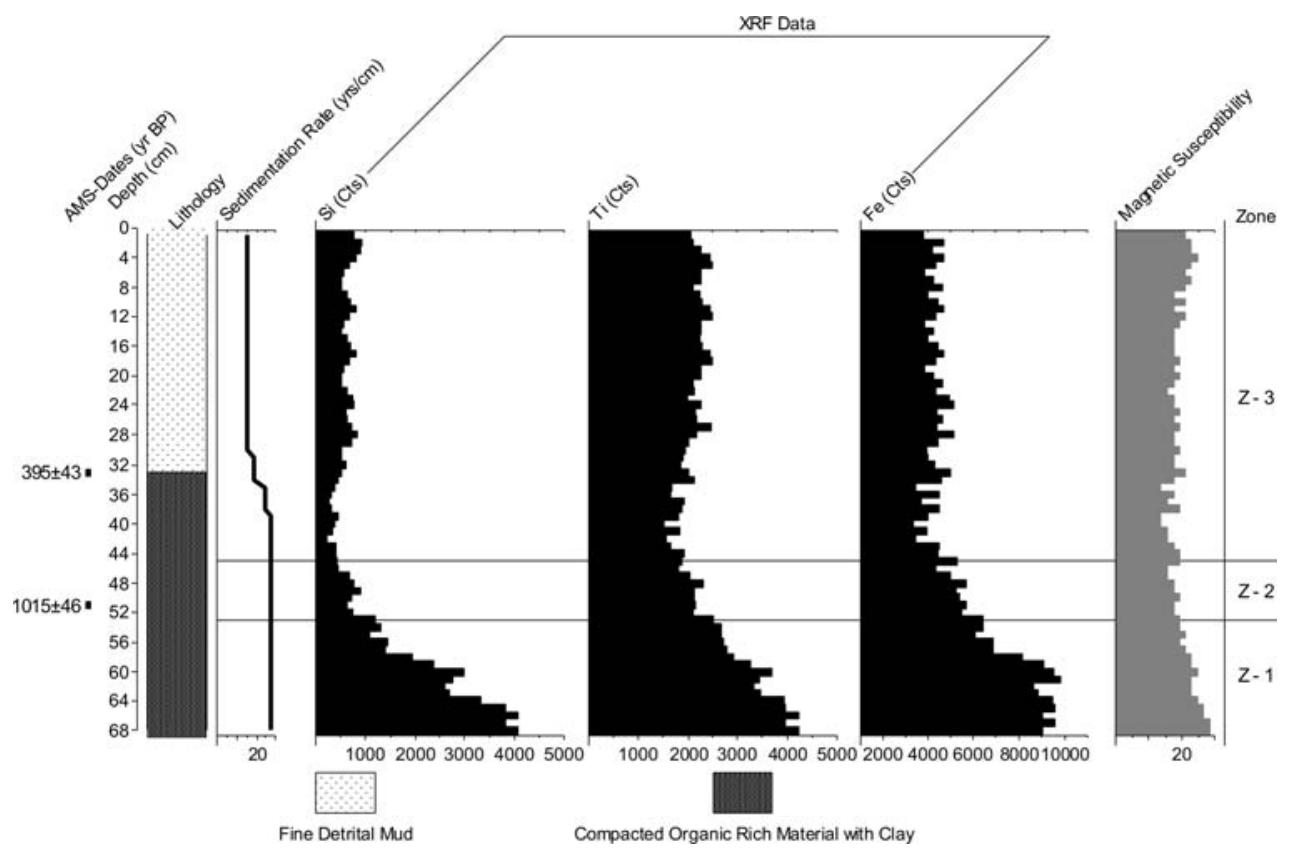

ECSF-Refugio. Areas not suitable for $Z$. mays cultivation, e.g. $40 \mathrm{~m}$ to the left and right of the Rio San Francisco and the small valleys, called Quebradas (empirical data) were buffered; and a Digital Elevation Model (DEM) was created. 'Krigging' raster interpolation proved to be the best way to rebuild the topography and to create a 3D Model. The inclination was calculated using surface analysis 'slope', reclassified and reconverted to vector data. 

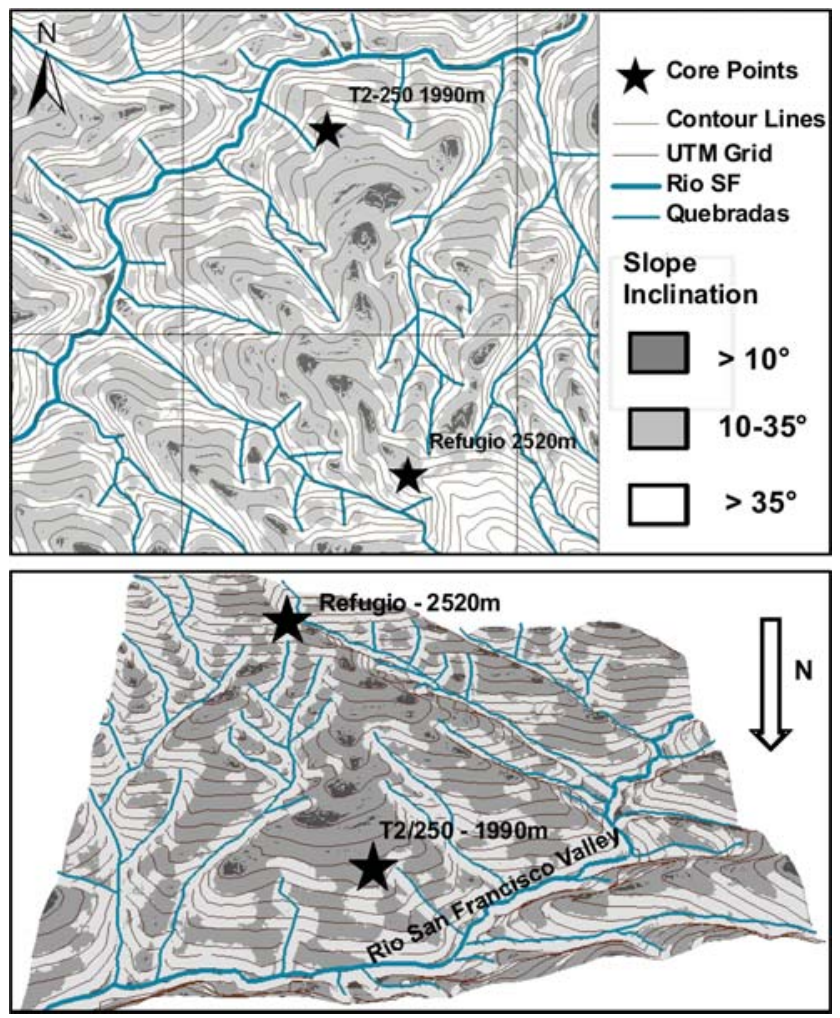

Fig. 8 Detailed GIS-based map and 3D sketch, including the lower part of the ECSF research area

\section{Results}

\section{Stratigraphy}

The $49 \mathrm{~cm}$ long soil monolith from ECSF-Cerro de Consuelo consists of grey silty clay $(49-19 \mathrm{~cm})$, grey silty clay with increasing organic content $(19-6 \mathrm{~cm})$ and brown organic material with roots $(6-0 \mathrm{~cm})$. According to the AMS radiocarbon dates, the possibility of a hiatus in the uppermost part of the core cannot be excluded. The $44 \mathrm{~cm}$ long soil monolith from ECSF-Refugio consists of decomposed dark-brown organic-rich material $(44-33 \mathrm{~cm})$ and brown organic material with roots $(33-0 \mathrm{~cm})$. The $48 \mathrm{~cm}$ long soil monolith from ECSF-T2/250 consists of decomposed dark-brown organic-rich material $(48-17 \mathrm{~cm})$ and brown organic material with roots $(17-0 \mathrm{~cm})$. The three soil monoliths were excavated from wet depressions. Deposition appears to have been undisturbed, but bioturbation cannot be entirely ruled out.

The $69 \mathrm{~cm}$ long sediment core from Laguna Zurita consists of compacted light-brown organic-rich material with clay $(69-33 \mathrm{~cm})$ and brown fine detritus mud (33$0 \mathrm{~cm}$ ).

Site specific data for the three soil monoliths from ECSF research area and the Laguna Zurita sediment core are given in Table 2.

\section{Chronology}

We obtained nine AMS radiocarbon dates (Table 3), seven from the three soil monoliths of the ECSF research area and two from the Laguna Zurita sediment core. Because macroscopic charcoal was absent from the upper parts of the soil monoliths from ECSF-Refugio and ECSF-T2/250, soil organic matter was dated. The dated material was contaminated by recent organic material (decomposed rootlets) and cannot be used for the chronology. Dating of fractions of soil organic matter obtained by alkali-acid extraction is promising, but which fraction renders the most accurate ${ }^{14} \mathrm{C}$ dates is still subject to debate (Tonneijck et al. 2006).
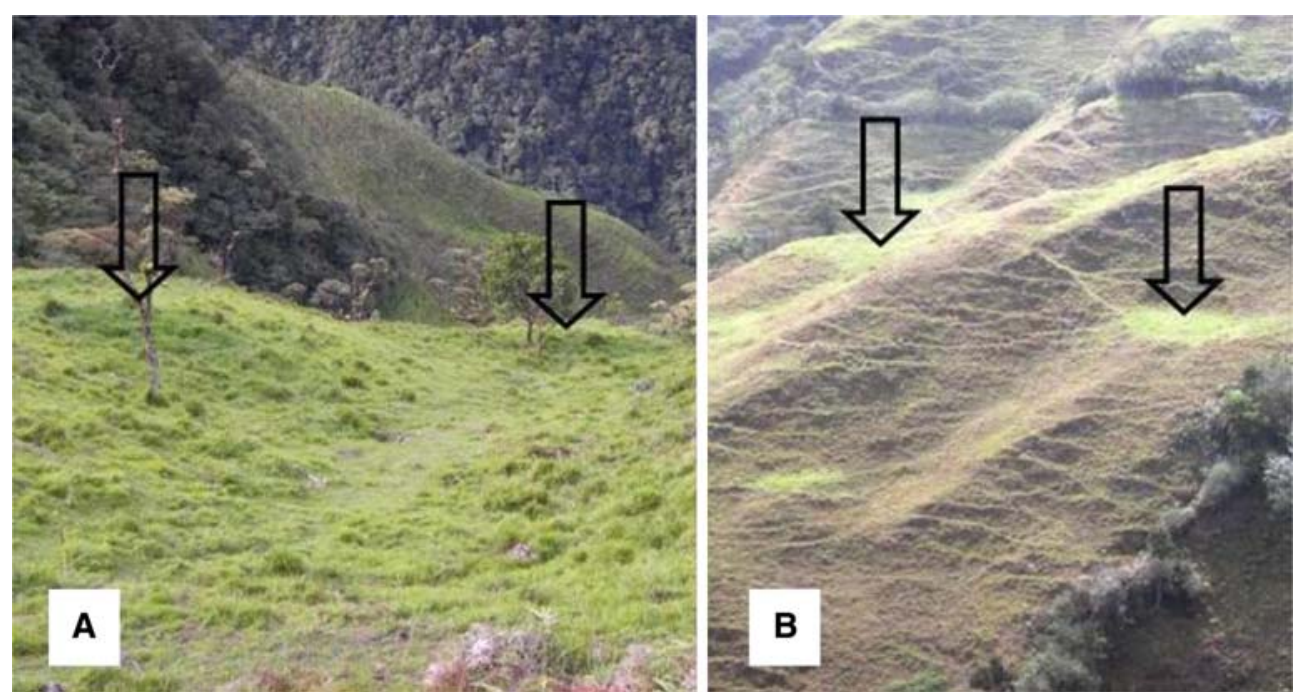

Fig. 9 Photograph of terraces above the small village of Sabanilla in the upper Rio San Francisco valley a and about 5 km southeast of Loja b 
Table 2 Site specific data of the three soil monoliths from the ECSF research area and Laguna Zurita sediment core

\begin{tabular}{lllllr}
\hline Record name & Material & Elevation $(\mathrm{m})$ & Core length $(\mathrm{cm})$ & Vegetation zone & Identified taxa \\
\hline ECSF-T2/250 & Soil monolith & 1,990 & 48 & LMF & 91 \\
ECSF-Refugio & Soil monolith & 2,520 & 44 & UMF & 72 \\
Laguna Zurita & Sediment core & 2,590 & 69 & UMF & 101 \\
ECSF-Cerro de Consuelo & Soil monolith & 3,155 & 49 & (Sub)-paramo & 87 \\
\hline
\end{tabular}

Table 3 AMS-radiocarbon dates, median calibrated ages and $1 \sigma$ age range of the three soil monoliths from ECSF research area and Laguna Zurita sediment core

\begin{tabular}{|c|c|c|c|c|c|c|}
\hline Laboratory code & $\begin{array}{l}\text { Core depth } \\
(\mathrm{cm})\end{array}$ & ${ }^{14} \mathrm{C}$ age в.P. & $\begin{array}{l}\text { Median } \\
\text { calibrated } \\
\text { age cal в.P. }\end{array}$ & $\begin{array}{l}1 \sigma \text { age range } \\
\text { cal B.P./rel. } \\
\text { probability }\end{array}$ & $\begin{array}{l}\text { Median } \\
\text { calibrated } \\
\text { age A.D. }\end{array}$ & $\begin{array}{l}1 \sigma \text { age range } \\
\text { A.D./rel. } \\
\text { probability }\end{array}$ \\
\hline Erl-9448 & 33 & $915 \pm 38$ & 777 & $732-800 / 0.95$ & 1173 & $1150-1218 / 0.95$ \\
\hline Erl-8901 & 21 & $-708 \pm 42$ & & & & \\
\hline Erl-8902 & 46 & $-533 \pm 48$ & & & & \\
\hline Erl-8377 & 34.5 & $854 \pm 45$ & 724 & $679-747 / 1.00$ & 1226 & $1203-1271 / 1.00$ \\
\hline Erl-8900 & 17 & $-602 \pm 34$ & & & & \\
\hline Erl-8803 & 18 & $1016 \pm 53$ & 863 & $\begin{array}{l}802-875 / 0.69 \\
897-929 / 0.30\end{array}$ & 1087 & $\begin{array}{l}1021-1053 / 0.30 \\
1075-1148 / 0.69\end{array}$ \\
\hline Erl-8904 & 36 & $1236 \pm 47$ & 1105 & $1055-1173 / 0.94$ & 845 & 777-895/0.94 \\
\hline Erl-8376 & 33 & $395 \pm 43$ & 405 & $\begin{array}{l}328-378 / 0.46 \\
439-490 / 0.48\end{array}$ & 1545 & $\begin{array}{l}1460-1511 / 0.48 \\
1572-1622 / 0.46\end{array}$ \\
\hline Erl-11031 & 51 & $1015 \pm 46$ & 862 & $804-872 / 0.72$ & 1088 & $1078-1146 / 0.72$ \\
\hline
\end{tabular}

Extrapolation of the AMS radiocarbon dates provides basal core ages of ca. 1300 cal B.P. for ECSF-Cerro de Consuelo, ca. 1100 cal B.P. for ECSF-Refugio, ca. 1200 cal B.P. for ECSF-T2/250 and ca. 1300 cal B.P. for Laguna Zurita.

Description of the pollen diagram of ECSF-Cerro de Consuelo

The pollen record of ECSF-Cerro de Consuelo in general shows no changes except a higher occurrence of Podocarpaceae, Hedyosmum, Ilex, Myrsine and Ericaceae in Zone C-1 (49-40 cm, older than ca. $1200 \mathrm{cal}$ B.P. [A.D. 750], 5 subsamples) (Fig. 3). Zone $C-2$ (40-20 cm, ca. 1200-900 cal B.P. [A.D. 750-1050], ten subsamples) is characterised by high pollen and charcoal concentrations. Zone C-3 (20-0 cm, younger than ca. 900 cal B.P. [A.D. 1050], 10 subsamples) shows a decrease in arboreal pollen (AP) such as Weinmannia and Melastomataceae; nonarboreal Poaceae pollen increases.

Description of the pollen diagram of ECSF-Refugio

Zone $R-1$ (44-38 cm, older than ca. 800 cal B.P. [A.D. $1150]$, three subsamples) is marked by an increase in AP and a decrease in non-arboreal pollen (NAP), especially Poaceae (Fig. 4). Fern spores are abundant and pollen concentration is high during this period. Zone $R-2$ (38$33 \mathrm{~cm}$, ca. 800-700 cal B.P. [A.D. 1150-1250], three subsamples) is characterised by constant values of AP and NAP. Melastomataceae pollen increases strongly. A single pollen grain of $Z$. mays occurred in one sample. Fern spores decrease strongly, and pollen and charcoal concentration are highest during this period. Zone $R-3(33-0 \mathrm{~cm}$, younger than ca. 700 cal B.P. [A.D. 1250], 17 subsamples) has constant values of AP and NAP. A single pollen grain of $Z$. mays occurred in one sample. Fern spores, especially the Blechnum auratum type, are abundant in the upper part of the record. Pollen and charcoal concentration are lowest during this period.

Description of the pollen diagram of ECSF-T2/250

Zone T-1 (48-33 cm, older than ca. 800 cal B.P. [A.D. 1150], eight subsamples) is marked by relatively low values of AP. NAP, especially Poaceae, have high values (Fig. 5). Single pollen grains of $Z$. mays occurred in two samples. Fern spores are most frequent during this period. Zone T-2 (33-15 cm, ca. 800-350 cal B.P. [A.D. 1150-1600], nine subsamples) shows a strong increase in AP, such as 
Weinmannia and Melastomataceae. NAP of Poaceae decreases from 25 to $5 \%$. Single pollen grains of $Z$. mays occurred in three samples. Fern spores are relatively frequent with a decreasing trend. Pollen and charcoal concentration are highest in this zone. Zone $T-3(15-0 \mathrm{~cm}$, younger than ca. 350 cal B.P. [A.D. 1600], eight subsamples) is marked by relatively high values of AP and lower values NAP than in the preceding zone. Pollen and charcoal concentration are lowest during this period.

Description of the pollen diagram of Laguna Zurita

Zone Z-1 (68-53 cm, ca. 1300-900 cal B.P. [A.D. 6501050], eight subsamples) is marked by relatively low values of AP (Fig. 6). NAP, especially Poaceae, have high values. Cyperaceae and spores of Isoetes decrease strongly in this zone. Fern spores are relatively rare and show no marked change in the record. Pollen and charcoal concentration decreases during this period. Zone Z-2 (53-45 cm, ca. 900-700 cal B.P. [A.D. 1050-1250], four subsamples) shows an increase in AP, such as Weinmannia and Melastomataceae. NAP, especially Poaceae, decreases. Cyperaceae decreases strongly, and spores of Isoetes are nearly absent during this period. Zone Z-3 (45-0 cm, ca. $700 \mathrm{cal}$ B.P. [A.D. 1250] to present, 12 subsamples) is marked by relatively high values of AP and lower values NAP than in the preceding zone. Pollen and charcoal concentration are relatively low during this period.

XRF-scanning and physical properties of the Laguna Zurita sediment core

The zonation of the pollen diagram (Z-1, Z-2 and Z-3) was adopted for XRF data. A correlation matrix (Spearman Rank Order Correlation) showed positive correlations of $\mathrm{Ti}$ to $\mathrm{K}, \mathrm{Fe}$ and $\mathrm{Si}(\mathrm{K}: r=0.715, \mathrm{Fe}: r=0.629$ and $\mathrm{Si}$ : $r=0.837$, $\mathrm{K}$ to Fe: $r=0.800$ and Si: $r=0.921$ and $\mathrm{Fe}$ to Si: $r=0.753, p<0.001$ ) (Fig. 7). Al was also significantly correlated to all four elements (Si: $r=0.476$, Fe: $r=0.519, \mathrm{~K}: r=0.558$, Ti: $r=0.452, p>0.001)$. As correlations among the mentioned elements are significant and show high correlation coefficients only $\mathrm{Si}, \mathrm{Ti}$ and $\mathrm{Fe}$ are plotted for palaeoenvironmental reconstruction. Counts of all other elements were too low for interpretation.

$\mathrm{Si}$, Ti and Fe decrease steadily from their highest values at the base of Zone Z-1. Si, Ti and Fe have relatively low counts in zones Z-2 and Z-3 with minima between 46 and $34 \mathrm{~cm}$. Magnetic susceptibility was correlated positively to Si: $r=0.638$, Fe: $r=0.535, \mathrm{~K}: r=0.567, \mathrm{Ti}: r=0.714$ and $\mathrm{Al}: r=0.458, p>0.001$ and broadly follows the records of $\mathrm{Si}, \mathrm{Ti}$ and $\mathrm{Fe}$.
GIS-based calculation of ancient Z. mays cultivation

About $54.6 \%$ of the area is has an inclination of $>35^{\circ}$ (unsuitable for $Z$. mays cultivation), $42.6 \%$ an inclination of $10-35^{\circ}$ (suitable for terraces), and $2.8 \%$ an inclination of $<10^{\circ}$ (terraces not necessary) (Fig. 8).

\section{Interpretation and discussion}

Vegetation, climate and fire dynamics on the elevational gradient

The pollen record of ECSF Cerro de Consuelo at 3,155 m elevation (Fig. 3) shows relatively few changes, except for higher occurrences of Podocarpaceae, Hedyosmum, Ilex, Myrsine and Ericaceae in zone C-1 prior to ca. $1200 \mathrm{cal}$ B.P. (A.D. 750). In zone C-2 between ca. 1200 and $900 \mathrm{cal}$ B.P. (A.D. 750-1050), the charcoal concentration is markedly higher than in the lower and upper parts of the core. The decrease in Podocarpaceae, Hedyosmum, Ilex, Myrsine and Ericaceae after the increase in fire frequency may suggest a shift of the tree line to lower elevations. Fires were probably human caused (e.g. uncontrolled burning), rather than natural (see also below). Pollen analysis from Pantano de Pecho $(3,870 \mathrm{~m})$ in the central Ecuadorian paramo documented shifts of the upper forest line prior to deforestation. The upper forest line moved upslope from 3,400 to $3,500 \mathrm{~m}$ during the period from ca. A.D. 1290 to 1315 , to its highest elevation of $3,750 \mathrm{~m}$ between ca. A.D. 1640-1765 (Wille et al. 2002). The reason for the low treeline in the Podocarpus National Park area is still under discussion. It may be a result of the so-called Andean depression, which probably caused a shift of the tree-line to a lower elevation. The modern upper-forest line in the Guandera Biological Reserve $\left(0^{\circ} 36^{\prime} \mathrm{N}\right)$, near the Ecuadorian-Colombian border, is at ca. 3,600 m (Bakker et al. 2008). The modern tree-line in northern and central Ecuador is at about 3,400-3,600 m. At El Tiro-Pass, on the road from Zamora to Loja $10 \mathrm{~km}$ west of ECSF research area, the modern tree-line is at ca. 2,800 m (Bader 2007). The position of the upper timberline (UTL) varies considerably along the neotropical cordilleras. Between $1^{\circ} \mathrm{N}$ and $17^{\circ} \mathrm{S}$, the UTL is between 4,000 and $4,800 \mathrm{~m}$, often formed by Polylepis woodlands. Open Polylepis stands occur up to $5,100 \mathrm{~m}$. At El Tiro-Pass, the UTL is between 2,790 and 2,820 m. At Cerro de Consuelo in the upper part of the ECSF research area, the UTL is between 2,730 and 3,040 m (Richter et al. 2008). The zone of 'low Neotropical UTL' is between $3^{\circ}$ and $7^{\circ} \mathrm{S}$, within the so-called Amotape-Huancabamba Floristic Zone (Weigend 2002). The UTL depression results from the absence of the usually superposing Polylepis belt, which is associated with 
extremely high precipitation in the eastern chain of the cordilleras in northern Peru and southern Ecuador, and it is absent from perhumid mountain regions (Kessler 1995).

The modern (sub)-paramo vegetation developed in zone C-3 after ca. $900 \mathrm{cal}$ B.P. (A.D. 1050). A decrease of Weinmannia, as well as a low fire frequency and the increase of Melastomataceae, Poaceae and Jamesonia, may indicate less human activity rather than cooler conditions at higher elevations.

The pollen record of ECSF Refugio at 2,520 m elevation (Fig. 4) shows a change in floristic composition, a decrease in Podocarpaceae, Ilex, Myrtaceae and ferns, as well as a strong increase in Melastomataceae in zone R-2 at ca. $800 \mathrm{cal}$ B.P. (A.D. 1150). Apparently the decrease in fire frequency in zone R-2 was responsible for the change in vegetation. The local extinction of the tree fern, probably Cyathea conjugata, might also be related to frequent burning during the past. The modern upper mountain forest vegetation became established in zone R-3 after ca. 800 cal B.P. (A.D. 1150).

The relatively frequent pollen of Clethraceae in the UMF zone probably originated from the tree Purdiaea nutans. Clethra itself is rare in the ECSF research area. Purdiaea nutans is a rare tree in the northern Andes, but exceptionally frequent in the ECSF research area between 2,150 m and $2,650 \mathrm{~m}$ elevation. The Purdiaea forest, with up to about $80 \%$ of individuals, is poor in other species (Mandl et al. 2008). A separation of Clethra and Purdiaea pollen in fossil archives is not possible. The pollen record of ECSF Refugio shows the lowest pollen and spore diversity; only 72 different taxa have been identified (Table 2). The low diversity may be a result of the dominance of Purdiaea. Data from pollen monitoring in the ECSF research area document a predominance of Purdiaea pollen between 2,300 and 2,550 $\mathrm{m}$ (Niemann and Behling 2009b).

The pollen record of ECSF T2/250 at 1,990 m elevation (Fig. 5) shows a marked change in floristic composition at ca. 350 cal B.P. (A.D. 1600). Weinmannia, Melastomataceae and Hedyosmum increased; Poaceae and ferns decreased. Apparently the marked decrease in fire was responsible for forest recovery in open areas on the slopes. The very high number of Poaceae and few Z. mays pollen grains, coupled with the high frequency of fires (evidence of macroscopic charcoal in the sediments), indicates burning activity near the study site before the change in floristic composition occurred. The lower amounts of Poaceae pollen and absence of $Z$. mays, coupled with the very low frequency of fires, indicate the absence of human activity near the core site in the ECSF area in zone T-3 after ca. 350 cal B.P. (A.D. $1600)$. The modern vegetation with a large presence of Weinmannia, Melastomataceae, Hedyosmum and Podocarpaceae became established in zone T-3 after ca. $350 \mathrm{cal}$ B.P. (A.D. 1600), indicating a successional forest recovery.
The pollen diagram from El Tiro-Pass $(2,810 \mathrm{~m})$, about $10 \mathrm{~km}$ from ECSF research area also shows a marked decrease in fire intensity during the last few centuries (Niemann and Behling 2008).

The pollen record of Laguna Zurita at 2,590 m elevation (Fig. 6) shows a high occurrence of Poaceae and a lower occurrence of Weinmannia, Melastomataceae and Clethra, associated with relatively high fire intensity, indicating a somewhat open forest around the lake in zone Z-1 before ca. 900 cal B.P. (A.D. 1050). Zone Z-2 shows a marked change in floristic composition between ca. 900 and 700 cal B.P. (A.D. 1050-1250). Poaceae decreased, while Weinmannia and Melastomataceae increased, indicating a change to a closed forest around the lake.

The high occurrence of Cyperaceae and Isoetes indicates marshy lake shores with a low lake level before ca. 1200 cal B.P. (A.D. 750). The marked decrease in Isoetes indicates a significant lake-level rise between ca. 1200 and $900 \mathrm{cal}$ B.P. (A.D. 750-1050). The decrease in Cyperaceae in zone Z-1 between ca. 900 and 700 cal B.P. (A.D. 10501250) reveals a diminishment of marshy lake shores. A lake level close to its modern level was reached in zone Z-3 after 700 cal B.P. (A.D. 1250). Because of the morphometry of the basin, a higher than modern lake level is not possible. Isoetes and Cyperaceae also indicate lake-level fluctuations at Laguna Cocha Caranga $(2,710 \mathrm{~m})$, $8 \mathrm{~km}$ southeast of the city of Loja (Niemann and Behling 2009a).

The palynological data clearly show a lake-level rise after ca. 1200 cal B.P. (A.D. 750), which could be explained by increased precipitation. A large number of palaeoenvironmental records from other sites in the northern Andes reveal increased precipitation during the late Holocene, indicating that the last millennium was the wettest of the preceding eight. For example, fossil-pollen records from the central Peruvian Andes at elevations above 4,000 m indicated a colder climate between ca. 2000-1000 в.P. and warm/wet conditions after ca. 1000 в.P. (Hansen et al. 1994). An increase in Alnus and Huperzia indicate moister conditions after ca. 800 cal B.P. at Laguna de Chochos $(3,285 \mathrm{~m})$ in the eastern Peruvian Andes (Bush et al. 2005). An increase in Alnus and fern spores indicate moister conditions after ca. 1800 year B.P. at Lake Surucucho $(3,200 \mathrm{~m})$ in the central Ecuadorian Andes (Colinvaux 1997). Three old river-channel lakes (Rio Napo) in the western Amazon basin of Ecuador showed regional flooding from ca. A.D. 700-1200 (Colinvaux et al. 1988a). Pollen data from the endorheic Lake Ayauch in the InterAndean Plateau of Ecuador reveal local evidence for a moist episode from ca. A.D. 400 to 1200 (Colinvaux et al. 1988b).

An alternative interpretation of the decreased values of $\mathrm{Fe}, \mathrm{Ti}$ and $\mathrm{Si}$ after ca. 1100 cal B.P. (A.D. 850) is that drier 
Table 4 Interpolated age of the floristic change and percentages of arboreal pollen before and after this time

\begin{tabular}{|c|c|c|c|c|c|c|}
\hline \multirow[t]{2}{*}{ Record name } & \multirow[t]{2}{*}{ Elevation (m) } & \multirow[t]{2}{*}{ Vegetation zone } & \multirow[t]{2}{*}{ Floristic change (interpolated age) } & \multicolumn{2}{|c|}{ Arboreal pollen: } & \multirow[t]{2}{*}{ Zea mays } \\
\hline & & & & Before $(\%)$ & After $(\%)$ & \\
\hline ECSF-Cerro de Consuelo & 3,155 & (Sub)-paramo & - & $65-70$ & $65-70$ & - \\
\hline Laguna Zurita & 2,590 & UMF & са. $900-700$ cal в.P. (A.D. $1050-1250$ ) & $65-70$ & $70-85$ & - \\
\hline ECSF-Refugio & 2,520 & UMF & Before ca. 800 cal B.P. (A.D. 1150) & 75 & $80-90$ & + \\
\hline ECSF-T2/250 & 1,990 & LMF & ca. $800-350$ cal в.P. (A.D. $1150-1600$ ) & $50-60$ & $75-85$ & ++ \\
\hline
\end{tabular}

conditions resulted in reduced sedimentary input (Fig. 7). The Fe, Ti and Si record is an indicator of fluvial terrigenuous sediment derived from bedrock; whereas magnetic susceptibility is an indicator of detrital input (e.g., Lamy et al. 2001, 2004; Niemann et al. 2009; Richter et al. 2006). Palaeoenvironmental studies from other sites in the northern Andes reveal drier conditions for the late Holocene. For example, pollen studies from lowland Amazonian Ecuador $(220 \mathrm{~m})$ reveal relatively wet conditions between ca. 3700 $1000 \mathrm{cal}$ B.P., whereas from ca. $1000 \mathrm{cal}$ B.P. to the present conditions have been relatively dry (Weng et al. 2002). During the last ca. 1,200 years, the input of forest pollen was greatly reduced due to human disturbance or climatic change in the Junin area $(4,100 \mathrm{~m})$ in the Central Peruvian Andes (Hansen et al. 1984). A palaeoclimatic record from the Cuzco region in Peru shows a long dry episode from ca. A.D. 900 to 1800 (Chepstow-Lusty et al. 2003). During the late Holocene, stable isotopes in ice cores from Quelccaya in the central Peruvian Andes (up to 6,000 m elevation), indicated a warmer period from ca. A.D. 1140 to 1250 , coeval with the 'Medieval Warm Period', and a cooler period between ca. A.D. 1300 and 1850, correlated with the 'Little Ice Age' in the northern hemisphere (Thompson et al. 2003). Palaeolimnological records from Lake Titicaca (Bolivia) show a wet period from ca. 1500 B.c. to A.D. 1100 and a dry period between ca. A.D. 1100 and 1400 (Binford et al. 1997). On the other hand, the decreasing values of $\mathrm{Fe}$, $\mathrm{Ti}$ and Si may have been the result of reduced vegetation coverage and change in floristic composition after ca. 900 cal B.P. (A.D. 1050).

Our data, as well as excavation near the lake shore during the field work did not reveal the origin of the lake, which could have been from a landslide or from human activities (water reservoir). The large number of palaeoterraces down-slope from the lake could have originated from irrigation during drier periods. If the lake was an irrigation reservoir, the increasing lake level may have resulted from reduced human activities (see below).

\section{Human impact}

The pollen records from ECSF T2/250, ECSF Refugio and Laguna Zurita in general showed a floristic change between ca. 900 and $350 \mathrm{cal}$ B.P. (A.D. 1050-1600). Arboreal pollen increased and non arboreal pollen (especially Poaceae) and ferns decreased (Table 4). This change is associated with significantly lower fire intensity (ECSF T2/250 and ECSF Refugio), indicating a reduction in human activities. This reduction may have resulted from civil conflicts in pre-Inca time, or the resettling politics of the Inca, or the onset of the Spanish conquest. After the reduction of human influence, the forest recovered in the upper Rio San Francisco valley. The earliest human activity in the region of Loja was dated to around 4000 в.P. (Guffroy 2004). In the eighth century, indigenous populations warred in the La Toma valley, about $10 \mathrm{~km}$ north of Loja (Guffroy 2006). In the middle of the 15th century the Inca occupied Ecuador, defeating the indigenous chiefdom called Palta. It was the strategy of the Inca to settle defeated populations in other regions of their empire, which was the fate of the Palta (Alvaredo 2002). The Saraguros are highland Indians, originally from the Titicaca region in Bolivia, who were resettled as workers and vassals in the Andean highlands northeast of Loja by the Incas (Pohle 2008). After an almost 70 year rule (A.D. 1463-1531), the Inca in southern Ecuador were defeated by the Spanish (Pohle 2008). The Spanish conquistadores brought Old World diseases to Ecuador, causing a decrease in the indigenous population (Alchon 1991). During the mid-17th century the Spanish lost control over the region between Loja and Zamora after fights with the indigenous population (Alvaredo 2002).

The occurrence of $Z$. mays shown in the pollen records of ECSF T2/250 before ca. 350 cal B.P. (A.D. 1600) and ECSF Refugio at ca. $800 \mathrm{cal}$ B.P. (A.D. 1150) indicates human activity. Zea mays pollen is more abundant at lower altitudes (ECSF T2/250), indicating that Z. mays was cultivated on the lower slopes (where overgrown terraces have been observed), close to the modern and probably past road systems. The latest floristic change is at study site ECSF T2/ 250 (350 cal B.P., A.D. 1600) indicating that the reduction of human activities occurred earlier at higher elevations. The multi-proxy lake-sediment record from Laguna Daniel Alvarez, located in the southern outskirts of Loja (2,200 m), clearly shows a change in human crop activities. At ca. 500 cal B.P. (A.D. 1450), Z. mays cultivation collapsed and Poaceae and Mimosa increased strongly, indicating that 
fields remained abundant. Cultivation of Amaranth was intensive after ca. 430 cal B.P. (A.D. 1520) concurrent with the arrival of the Spanish (Matthias 2008). Results from Ecuadorian Amazonia and Colombia also show a reduction of human activities during the late Holocene. After ca. 2340 cal B.P. grassy vegetation remained abundant in the Colombian Cauca Valley. The presence of crop taxa (e.g. $Z$. mays) and an increase in charcoal point to the presence of pre-Columbian people. After ca. 870 cal B.P., expansion of secondary forest taxa may indicate depopulation and abandonment of previously cultivated land. After ca. 490 cal B.P., possibly related to the Spanish conquest, secondary forest expanded and charcoal concentrations increased, possibly indicating further reduction of cultivated land (Berrio et al. 2002). The pollen record from Lake Ayauch $(500 \mathrm{~m})$, southeastern Ecuadorian Amazonia, shows Z. mays cultivation between ca. 2,960 and ca. 720 cal B.P. The abandonment of $Z$. mays cultivation may have been due to social unrest (Bush and Colinvaux 1988).

During the field work, a high number of simple terraces, mostly on slopes of $10-35^{\circ}$, were observed in the Rio San Francisco valley, as well as throughout the Loja region (Fig. 9). The high number of terraces indicates human activities during the past. Some overgrown terraces have been identified in the lower part of the ECSF research area (below ca. 2,600 m), most of them close to the valley bottom. Where field mapping is restricted, due to closed forests or inaccessibility, GIS calculations indicate that nearly half of the calculated area, including the lower part of the ECSF research area below 2,600 m (Fig. 8), offers potential places for Z. mays cultivation. About $42.6 \%$ of the area has an inclination of $10-35^{\circ}$ (suitable for terraces), $2.8 \%$ an inclination of $<10^{\circ}$ (terraces not necessary for cultivation), and $54.6 \%$ an inclination of $>35^{\circ}$ (unsuitable for Z. mays cultivation).

Dated terraces in the Loja region are of pre-Inca and Inca age (Guffroy, personal communication). One of these terraces (Fig. 9), located $3 \mathrm{~km}$ east of the ECSF research area, just above the small village of Sabanilla (ca. $1,800 \mathrm{~m}$ ), was sampled for pollen and spores (radiocarbon dates are not available). Relatively low values of arboreal pollen and some pollen of $Z$. mays in the lowermost sample suggest agricultural activities during this time, the period before the floristic change. The samples from the middle part of the record show high values of arboreal pollen and low amounts of Poaceae pollen, indicating a closed forest, characteristic of the late-Holocene reduction of human activities. The uppermost sample shows a high occurrence of Poaceae pollen and coprophilous Ascospores, suggesting an open vegetation type with intensive pasturing in modern times (Niemann 2008). The resettling of the Rio San Francisco valley was started in the mid-20th century by Mestizes Colonos, settlers from other parts of Ecuador
(Pohle 2008). The construction of the road between Loja and Zamora, and the power station next to the ECSF research area in the late 1950 s are responsible for new settlements and associated landscape disturbance during the last few decades. The decrease in arboreal pollen during the last ca. 50 years, shown in the records Laguna Zurita and ECSF Refugio, also indicate this increased human impact. In modern times, the ECSF research area has been a closed forest system within a disturbed landscape.

\section{Conclusions}

Past fires have markedly influenced the floristic stability of the mountain rainforest ecosystem in the upper Rio San Francisco valley, including the ECSF research area. The high occurrence of grasses and some maize plantations, document past human activities in the upper Rio San Francisco valley. After the reduction in fire frequency and presumably human influence after ca. 900-350 cal B.P., forest began to invade open areas. The reduction in human activities may have been the result of political unrest, including civil conflicts in pre Inca time, the resettling politics of the Inca, and the arrival of the Spanish. A convincing case for a climatic cause for the lake-level rise at Laguna Zurita before 700 cal B.P. cannot be made, and it may have an anthropogenic origin.

The record of human impact indicates that the mountain rainforest of the ECSF research area is not virgin. However, more than four centuries without marked disturbances suggests that the forest represents a relatively 'natural' stage of a mountain rainforest ecosystem.

Acknowledgments Felix Matt (research station leader) is thanked for his logistical support and for his information about the study region. Thanks to Ursula Röhl (MARUM, University of Bremen) for using the XRF-scanner, Thorsten Friedrich (Geosciences, University of Bremen) for using the MS-scanner and to Torsten Haberzettl (Geoscience Centre, University of Göttingen) for using the software to plot physical properties. The project FOR 402/D1 (Vegetation-, climate- and fire dynamics in the Podocarpus National Park region) is kindly funded by the Deutsche Forschungsgemeinschaft (DFG).

Open Access This article is distributed under the terms of the Creative Commons Attribution Noncommercial License which permits any noncommercial use, distribution, and reproduction in any medium, provided the original author(s) and source are credited.

\section{References}

Alchon SA (1991) Native society and disease in colonial Ecuador. Cambridge University Press, Cambridge

Alvaredo PJ (2002) Historia de Loja y su Provincia. Municipio de Loja, Industria grafica Senefelder 
Bader MY (2007) Tropical alpine treelines; how ecological processes control vegetation patterning and dynamics. Ph.D. thesis, Wageningen University, Wageningen, The Netherlands

Bakker C, Moscol Olivera M, Hooghiemstra H (2008) Holocene environmental change at the upper timberline in northern Ecuador. Holocene 18:1-17

Barthlott W, Mutke J, Rafiqpoor MD, Kier G, Kreft H (2005) Global centres of vascular plant diversity. Nova Acta Leopoldina 92:6183

Beck E, Bendix J, Kottke I, Makeschin F, Mosandl R (2008a) Gradients in a tropical mountain ecosystem of Ecuador. Ecological studies 198. Springer, Berlin

Beck E, Makeschin F, Haubrich F, Richter M, Bendix J, Valerezo C (2008b) The ecosystem (Reserva Biológica San Francisco). In: Beck E, Bendix J, Kottke I, Makeschin F, Mosandl R (eds) Gradients in a tropical mountain ecosystem of Ecuador. Ecological studies 198. Springer, Berlin, pp 1-14

Behling H (1993) Untersuchungen zur spätpleistozänen und holozänen Vegetations- und Klimageschichte der tropischen Küstenwälder und der Araukarienwälder in Santa Catarina (Südbrasilien). Diss Bot 206, Cramer, Berlin

Bendix J, Fabian P, Rollenbeck R (2004) Gradients of fog and rain in a tropical montane cloud forest of southern Ecuador and its chemical composition. In: Proceedings 3rd international conference on fog, fog collection and dew, 11-15 October 2004, Cape Town, South Africa

Bendix J, Rollenbeck R, Richter M, Fabian P, Emck P (2008) Climate. In: Beck E, Bendix J, Kottke I, Makeschin F, Mosandl $\mathrm{R}$ (eds) Gradients in a tropical mountain ecosystem of Ecuador. Ecological studies 198. Springer, Berlin, pp 63-74

Berrio JC, Hooghiemstra H, Marchant R, Rangel O (2002) Lateglacial and Holocene history of the dry forest area in the south Colombian Cauca Valley. J Quatern Sci 17:667-682

Binford MW, Kolata AL, Brenner M, Janusek JW, Seddon MT, Abbott M, Curtis JH (1997) Climate variation and the rise and fall of an Andean civilization. Quatern Res 47:235-248

Bush MB, Colinvaux PA (1988) A 7000-year pollen record from the Amazon lowlands, Ecuador. Vegetatio 76:141-154

Bush MB, Hansen BCS, Rodbell DT, Seltzer GO, Young KR, Leon B, Abbott MB, Silman MR, Gosling WD (2005) A 17 000-year history of Andean climate and vegetation change from Laguna de Chochos, Peru. J Quatern Sci 20:703-714

Chepstow-Lusty A, Frogley MR, Bauer BS, Bush MB (2003) A late Holocene record of arid events from the Cuzco region, Peru. J Quatern Sci 18:491-502

Colinvaux PA (1997) Glacial and postglacial pollen records from the Ecuadorian Andes and Amazon. Quatern Res 48:69-78

Colinvaux PA, Frost M, Frost I, Liu K-B, Steinitz-Kannan M (1988a) Three pollen diagrams of forest disturbance in the western Amazon basin. Rev Palaeobot Palynol 55:73-81

Colinvaux PA, Olson K, Liu K-B (1988b) Late-glacial and Holocene pollen diagrams from two endorheic lakes of the Inter-Andean plateau of Ecuador. Rev Palaeobot Palynol 55:83-99

Emck P (2007) A climatology of south Ecuador-with special focus on the major Andean ridge as Atlantic-Pacific climate divide. Diss Univ. Erlangen-Nürnberg, Germany

Faegri K, Iversen J (1989) Textbook of pollen analysis. Wiley, New York

Grimm EC (1987) CONISS: a Fortran 77 program for stratigraphically contrained cluster analysis by the method of the incremental sum of squares. Comp Geosci 13:13-35

Guffroy J (2004) Catamayo precolombino. Investigaciones arqueologicas en la provincia de Loja (Ecuador). IRD editions, Paris

Guffroy J (2006) El Horizonte corrugado: correlations estilisticas y culturales. Bulletin de l'Institut Francais d'Etudes Andines 35:1-13
Hansen BCS, Wright HE, Bradbury JP (1984) Pollen studies in the Junin area, Central Peruvian Andes. Geol Soc Am Bull 95:1454-1465

Hansen BCS, Seltzer GO, Wright HE (1994) Late quaternary vegetation change in the central Peruvian Andes. Palaeogeogr Palaeoclim Palaeoecol 109:263-285

Homeier J, Werner FA (2005) Preliminary checklist of the spermatophytes of the Reserva San Francisco (Province Zamora-Chinchipe, Ecuador). Dept. of Plant Ecology, Albrecht-von-Haller-Institute for Plant Sciences, Univ. Göttingen, Germany

Homeier J, Werner FA, Gradstein SR, Breckle S-W, Richter M (2008) Potential vegetation and floristic composition of Andean forests in south Ecuador, with a focus on the RBSF. In: Beck E, Bendix J, Kottke I, Makeschin F, Mosandl R (eds) Gradients in a tropical mountain ecosystem of Ecuador. Ecological Studies 198. Springer, Berlin, pp 87-100

Hooghiemstra H (1984) Vegetation and climatic history of the High Plain of Bogota, Colombia. Diss Bot 79, Cramer, Vaduz

Kessler M (1995) Polylepis-Wälder Boliviens: Taxa, Ökologie, Verbreitung und Geschichte. Diss Bot 246, Cramer, Vaduz

Lamy F, Hebbeln D, Röhl U, Wefer G (2001) Holocene rainfall variability in southern Chile: a marine record of latitudinal shifts of the Southern Westerlies. Earth Planet Sci Lett 185:369-382

Lamy F, Kaiser J, Ninnemann U, Hebbeln D, Arz HW, Stoner J (2004) Antarctic timing of surface water changes off Chile and Patagonian ice sheet response. Science 304:1959-1962

Litherland M, Aspen JA, Jemielita RA (1994) The metamorphic belts of Ecuador. Overseas Memoir of the British Geological Survey 11:1-147

Lozano P, Delgado T, Aguirre Z (2003) Estado actual de la flora endemica exclusive y su distribucion en el Occidente del Parque Nacional Podocarpus. Funbotanica y Herbario y Jardin Botanico, Loja, Ecuador

Mandl N, Lehnert M, Gradstein SR, Kessler M, Abiy M, Richter M (2008) The unique Purdiaea nutans forest of southern Ecuadorabiotic characteristics and cryptogamic diversity. In: Beck E, Bendix J, Kottke I, Makeschin F, Mosandl R (eds) Gradients in a tropical mountain ecosystem of Ecuador. Ecological studies 198. Springer, Berlin, pp 275-280

Matthias I (2008) Rekonstruktion der Umwelt- und Siedlungsgeschichte von Loja durch Multiproxy-Analysen an limnischen Sedimenten der Laguna Daniel Alvarez in Südecuador. Diploma thesis, Univ. Göttingen, Germany (unpublished)

McCormac FG, Hogg AG, Blackwell PG, Buck CE, Higham TFG, Reimer PJ (2004) SHCal04 southern hemisphere calibration 011.0 cal kyr B.P. Radiocarbon 46:1087-1092

Niemann H (2008) Late quaternary vegetation, climate and fire dynamics in the Podocarpus National Park region, southeastern Ecuadorian Andes. Diss Univ. Göttingen, Germany. http:// webdoc.sub.gwdg.de/diss/2008/niemann/

Niemann H, Behling H (2008) Late quaternary vegetation, climate and fire dynamics inferred from the El Tiro record in the southeastern Ecuadorian Andes. J Quatern Sci 23:203-212

Niemann H, Behling H (2009a) Late Pleistocene and Holocene environmental change inferred from the Cocha Caranga sediment and soil records in the southeastern Ecuadorian Andes. Palaeogeogr Palaeoclim Palaeoecol 276:1-14

Niemann H, Behling H (2009b) Vegetation/modern pollen rain relationship on an altitudinal transect between 1800 and $3200 \mathrm{~m}$ in the Podocarpus National Park region, southeastern Ecuadorian Andes. Rev Palaeobot Palynol (in review)

Niemann H, Haberzettl T, Behling H (2009) Holocene climate variability and vegetation dynamics inferred from the (11 700 cal B.P.) Laguna Rabadilla de Vaca sediment record in the southeastern Ecuadorian Andes. Holocene 19:307-316

Pohle P (2008) The People Settled Around Podocarpus National Park. In: Beck E, Bendix J, Kottke I, Makeschin F, Mosandl R (eds) 
Gradients in a tropical mountain ecosystem of Ecuador. Ecological studies 198. Springer, Berlin, pp 25-36

Richter M, Moreira-Munoz A (2005) Climatic heterogeneity and plant diversity in southern Ecuador experienced by phytoindication. Rev Peruvian Biol 12:217-238

Richter T, Van der Gaast S, Koster B, Vaars A, Gieles R, De Stigter H, De Haas H, Van Weering T (2006) The Avaatech XRF core scanner: technical description and applications to NE Atlantic sediments. In: Rothwell RG (ed) New techniques in sediment core analysis. Geological Society, Special Publications 267, London, pp 39-50

Richter M, Diertl K-H, Peters T, Bussmann RW (2008) Vegetation structures and ecological features of the upper timberline ecotone. In: Beck E, Bendix J, Kottke I, Makeschin F, Mosandl $\mathrm{R}$ (eds) Gradients in a tropical mountain ecosystem of Ecuador. Ecological studies 198. Springer, Berlin, pp 275-280

Stuiver M, Reimer P (1993) Extended ${ }^{14} \mathrm{C}$ database and revised CALIB radiocarbon calibration program. Radiocarbon 35:215230

Thompson LG, Mosley-Thompson E, Arnao BM (1984) El NinoSouthern Oscillation events recorded in the stratigraphy of the tropical Quelccaya ice cap, Peru. Science 226:50-53

Thompson LG, Mosley-Thompson E, Dansgaard W, Grootes PM (1986) The Little Ice Age as recorded in the stratigraphy of the tropical Quelccaya ice cap. Science 234:361-364
Thompson LG, Mosley-Thompson E, Davis ME, Lin P-N, Henderson K, Mashiotta TA (2003) Tropical glacier and ice core evidence of climate change on annual to millennial time scales. Clim Change 59:137-155

Tjallingii R, Röhl U, Kölling M, Bickert T (2007) Influence of the water content on $\mathrm{X}$-ray fluorescence core-scanning measurements in soft marine sediments. Geochem Geophys Geosys 8, Q02004. doi:02010.01029/02006GC001393

Tonneijck FH, Van der Plicht J, Jansen B, Verstraten JM, Hooghiemstra $\mathrm{H}$ (2006) Radiocarbon dating of soil organic matter fractions in Andesols in northern Ecuador. Radiocarbon 48:337353

Weigend M (2002) Observations on the biogeography of the Amotape-Huancabamba zone in northern Peru. Bot Rev 68:38-54

Weng C, Bush MB, Athens JS (2002) Holocene climate change and hydrarch succession in lowland Amazonian Ecuador. Rev Palaeobot Palynol 120:73-90

Wille M, Hooghiemstra H, Hofstede R, Fehse J, Sevink J (2002) Upper forest line reconstruction in a deforested area in northern Ecuador based on pollen and vegetation analysis. J Trop Ecol 18:409-440 